\title{
ІНТЕЛЕКТУАЛЬНИЙ АНАЛІЗ ЗЕМЛЕКОРИСТУВАННЯ В РОЗРІЗІ ТЕРИТОРІАЛЬНИХ ГРОМАД УКРАЇНИ
}

\author{
В.В. Путренко, С.В. Гапон \\ Національний технічний університет Украйни \\ «Київський політехнічний інститут ім. Ігоря Сікорського» \\ пр. Перемоги, 37, Київ, 03056, Україна \\ e-mail: putrenko@wdc.org.ua
}

Отримання актуальної та достовірної геопросторової інформації про особливості території $\epsilon$ запорукою проведення успішного планування територіального розвитку та переходу до сталих форм господарювання. В цьому контексті забезпечення органів державного управління та планування якісними геопросторовими даними $\epsilon$ одним із найважливіших завдань. Джерелами таких даних у більшості випадків виступають дані дистанційного зондування Землі (ДЗ3), які після певної технічної підготовки можуть використовуватися для вирішення прикладних завдань моніторингу та аналізу території. В останні роки все більшого значення набувають дані космічної зйомки, а також широко використовуються результати лідарної зйомки та БПЛА різного класу для отримання знімків у режимі близькому до реального часу.

Одним із базових продуктів, який може бути отримано на основі обробки даних Д33 є карта земного покриву або землекористування. Подібні дані становлять основу для організації та управління територією територіальних громад України, що актуально в контексті процесів децентралізації.

Особливо важливо мати динамічний ряд для відслідковування тенденцій в зміні видів землекористування. Враховуючи важливість цих даних останні 30 років у всьому світі реалізуються міжнародні та регіональні програми та ініціативи, що направлені на дослідження земного покриву та створення карт землекористування. Найбільш відомими та в певному змісті піонерськими стали такі проекти, як отримання світового покриття GLC2000 та успішна реалізація європейської програми CORINE, яка заклала єдині стандарти відображення типів землекористування в Свропейському Союзі. Оскільки Україна не приймала участь в програмі CORINE територія країни довгий час залишалась без якісного опису земного покриву. Відповідно до цього територіальне планування та регіональне управління залишались без інформації про землекористування і відповідно поступались європейським методам у прийнятті рішень [1].

Метою дослідження є аналіз земного покриву території України для цілей державного управління та адміністрування з використанням даних продукту Globeland 30. Завданнями дослідження $є$ вивчення особливостей продукту Globeland 30, методів отримання даних земного покриву, розробка схеми та методики обробки даних для задач дослідження території України, отримання та інтелектуальний аналіз зональних даних для адміністративних одиниць України з використанням індексів ентропії Шеннона [2]. 
Співвідношення між типами землекористування може бути одним із показників наближення до сталого розвитку території. Однією із базових оцінок ландшафтного біорізноманіття є індекс Шеннона, який може бути успішно використаний для аналізу співвідношення між видами земного покриву [3].

Теорія інформації грунтується на вивченні ймовірності настання ланцюга подій. Результат виражається в одиницях невизначеності, або інформації. Шеннон в 1949 році вивів функцію, яка стала називатися індексом різноманіття Шеннона. Розрахунки індексу різноманіття Шеннона припускають, що типи землекористування потрапляють у вибірку випадково 3 «невизначено великої» (тобто практично нескінченної сукупності) генеральної сукупності, причому у вибірці представлені всі види генеральної сукупності. Невизначеність буде максимальною, коли всі події $(N)$ матимуть однакову ймовірність настання $\left(P_{i}=N_{i} / N\right)$. Вона зменшується в міру того, як частота деяких подій зростає в порівнянні з іншими, аж до досягнення мінімального значення (нуля), коли залишається одна подія і $є$ впевненість в ії настанні.

$$
H=-\sum_{i=1}^{n} \quad p_{i} \log _{2} p_{i}
$$

де величина $P_{i}$ - доля видів землекористування $i$-го типу.

Причини помилок в оцінці різноманіття з використанням цього індексу полягають в тому, що неможливо включити до вибірки всі види типів землекористування [4].

При розрахунку індексу Шеннона часто використовується двійковий логарифм, але прийнятним $€$ також використовувати інші підстави логарифма (десятичний, натуральний). Індекс Шеннона зазвичай варіює в межах від 1,5 до 3,5, дуже рідко перевищуючи 4,5.

Дисперсію індексу Шеннона $\left(\operatorname{VarH}^{\prime}\right)$ розраховують за формулою :

$$
\operatorname{Var} H^{\prime}=\frac{\sum p_{i}\left(\ln \ln p_{i}\right)^{2}-\left(\sum p_{i} \ln p_{i}\right)^{2}}{N}+\frac{S-1}{2 N^{2}} .
$$

Якщо значення індексу Шеннона розрахувати для декількох вибірок, то отриманий розподіл величин підпорядковується нормальному закону. Ця властивість дає можливість застосовувати потужну параметричну статистику, включаючи дисперсійний аналіз. Застосування порівняльних параметричного і дисперсійного аналізу корисно при оцінці різноманіття різних середовищ існування, коли є повторності.

Для перевірки значущості відмінностей між вибірковими сукупностями значень індексу Шеннона Хатчесон запропонував використовувати параметричний критерій Стьюдента:

$$
t=\frac{\mathrm{H}_{1}^{\prime}-\mathrm{H}_{2}^{\prime}}{\left(\text { VarH }_{1}{ }_{1}-\operatorname{VarH}_{2}^{\prime}\right)^{1 / 2}} .
$$

Число ступенів свободи визначається за рівнянням:

$$
d f=\frac{\left(\operatorname{VarH}_{1}+\operatorname{VarH}_{2}^{2}\right)^{2}}{\left(\frac{\left.\operatorname{VarH}_{1}\right)^{2}}{N_{1}}+\left(\operatorname{VarH}_{2}\right)^{2} / N_{2}\right.},
$$

де $N_{l}$ i $N_{2}$ - загальне число типів в двох вибірках.

На основі індексу Шеннона можна обчислити показник вирівнювання $E$ (відношення спостережуваного різноманіття до максимального):

$$
E=\frac{\mathrm{H}^{\prime}}{L n S}
$$

$E \hat{\imath}[0,1]$, причому $E=1$ при рівному достатку всіх типів.

Розрахунок індексу Шеннона для адміністративних одиниць рівня району показує, що найбільші значення різноманіття притаманні двом типам адміністративних одиниць. До першого типу відносяться адміністративні одиниці півночі України, що знаходяться у Поліссі. Відповідно до цього, можемо вважати, що різноманіття покривів в цих районах забезпечується за рахунок природних ландшафтів у поєднанні з формами господарської діяльності. Підтримка високого ландшафтного різноманіття сприяє сталому розвитку території. До подібних територій з високим різноманіттям природних земних покровів відносяться частина карпатських районів, а також райони уздовж крупних річок, зокрема Дніпра. Другий тип районів з високим значенням індексу 
Шеннона був отриманий за рахунок антропогенезованих та урбанізованих ландшафтів, які мають переважаюче значення економічних ресурсів. Більшість таких районів зосереджені у східній та центральній Україні. Західна та центральна частина України характеризується низькими значеннями різноманіття, що вказує на переважання змінених ландшафтів під впливом сільського господарства та урбанізації. Ці території мають низький потенціал сталого розвитку за рахунок високого рівня заміни природних ландшафтів антропогенними. Певна частина районів мають низьке значення за рахунок переважання природних ландшафтів. Це стосується деяких районів в Карпатах, де переважають лісові масиви, але не розвинута інфраструктура та низка щільність населення.

В результаті можна зазначити, що наявність глобального продукту аналізу земного покриву Globeland 30 надає можливість для здійснення ефективної політики в галузі регіонального управління та територіального планування з урахуванням реально існуючого розподілу типів землекористування. Продукт Globeland 30 створено на основі автоматизованої класифікації знімків Landsat TM і ETM + та знімків з китайського супутника HJ-1. Роздільна здатність та геометрична точність Globeland 30 дорівнюють характеристикам знімків Landsat і становлять відповідно 30 та 75 м. Оцінка якості розпізнавання типів земних покровів становить в середньому 83.51\%. За методом класифікації Globeland 30 дуже схоже з верхніми рівнями класифікації CORINE, що робить ï̈ використання інтероперабельним для участі в європейських проектах.

В ході дослідження було розроблено схему та методику обробки даних для задач дослідження території України, яка складається 3 етапів предпроцесінга даних та отримання зональної статистики. На основі отриманих статистичних даних було побудовано та досліджено розподіл основних типів земних покровів в Україні. 3 метою отримання інтегральних оцінок розподілу типів землекористування використано аналіз різноманіття на основі індексу Шеннона. За результатами обрахунків усі типи районів розподілено у двовимірному просторі на чотири групи в залежності від співвідношення значення індексу Шеннона та частки урбанізованих територій. До групи з високим природним різноманіттям та потенціалом сталого розвитку потрапили окремі райони Полісся, Придніпров'я та Карпат. До групи з високим економічним потенціалом та різноманіттям антропогенних форм землекористування потрапили окремі райони сходу та центру країни, а також міські агломерації. Група районів 3 низьким різноманіття ландшафтів антропогенного походження містить більшість районів сільськогосподарської спеціалізації на півдні країни. Група районів 3 низьким різноманіття ландшафтів природного походження відноситься до слаборозвинутих територій гірської частини країни.

Подальші дослідження пов'язані з аналізом даних землекористування на основі інших показників різноманіття та співвідношення структур, кластерізації адміністративних одиниць 3 використанням методів машинного навчання.

\section{Література:}

1. Бродский Л. Проект INTAS по разработке автоматизированной технологии классификации земных покрытий: научные задачи, основные результаты и перспективы / Л. Бродский, Е. И. Бушуев, В. И. Волошин, А. А. Козлова, О. И. Паршина, М. А. Попов, В. И. Саблина, А. И. Сахацкий, А. В. Сиротенко, Т. Соукуп, С. А. Станкевич, А. Г. Тарарико // Космічна наука $\mathrm{i}$ технологія. 2009. Т. 15. № 2. С. 36-48.

2. Попов М. А., Станкевич С. А., Сахацкий А. И., Козлова А. А. Использование полного набора нормализованных межканальных индексов многоспектральных космических изображений при классификации покрытий ландшафта // Уч. зап. Таврического нац. ун-та им. В. И. Вернадского. - 2007. - 20 (59), № 1. - С. 175-182.

3. Bossard M., Feranec J., Otahel J. The revised and supplemented Corine Land Cover nomenclature // Techn. Rept EEA. - 2000. - N 38. - 110 p.

4. Brian O'Connor, Cristina Secades, Johannes Penner, Ruth Sonnenschein, Andrew Skidmore, Neil D. Burgess \& Jon M. Hutton Earth observation as a tool for tracking progress towards the Aichi Biodiversity Targets // Remote Sensing in Ecology and Conservation/ - y John Wiley \& Sons Ltd, 2015/ $-19-27$ 